\title{
DISCUSSION.
}

\section{WHAT IS SOCIAL PSYCHOLOGY?}

\section{Editor Psychological Bulletin:}

Some criticisms on the view I take as to the scope of social psychology in a recent text-book on the subject ${ }^{1}$ seem to make it worth while for me to present such justification as I have to offer.

It is becoming clear that there are two competing notions as to what is the subject matter of social psychology. One is the notion held by Baldwin, McDougall and others that social psychology is the psychology of the individual in association; the other is the view represented by Tarde and other continental writers that social psychology is the psychology of society, or, if you please, the consideration of great-scale psychic phenomena. The writer has endeavored to make this conception more precise by defining it as the study of " the psychic planes and currents that come into existence among men in consequence of their association."

The former conception would make social psychology a branch of psychology; the latter would make it a branch of sociology. There is no doubt that there are here two rising and substantial bodies of valuable knowledge competing for the use of the same designation. Whichever succeeds in getting itself called 'social psychology, the other will, no doubt, contrive to flourish under some other name. The point at issue is not of primary importance, but it is worth while to offer some reasons why it seems better to reserve the term 'social psychology' to designate a branch of sociology.

If out of human psychology be carved a province to be known as social psychology, having to do with all phenomena of the individual mind which arise out of or imply association with other minds, then logically the rest of the science will be known as individual psychology,' and will deal with everything in mental development which does not presuppose association. It is hardly necessary to point out that no such line of cleavage has been recognized by the psychologists, nor is it likely to be. A large part of what has been called simply 'psychology' would have to be turned over to 'social psychology.' Not only would the study of the emotions fall under the latter head,

'Social Psychology. An Outline and Source Book. New York, 1908. 
seeing that most of them - love, jealousy, resentment, shame, envy, pity, gratitude, reverence, ambition, etc. - imply a relation to other beings like ourselves, $i$. e., association, but that of the higher cognitive processes as well - comparison, analysis, abstraction, conception, judgment, reasoning, invention, self-consciousness. Not only would ' individual psychology' come off rather badly in the division, but it would be put in the absurd position of having a myth or a monstrosity for its subject matter - for we have never met nor are likely to meet human beings whose mental life has not been built up on a basis of interplay with other minds, while it is probable that a human being reared under strict isolation would be scarcely distinguishable from an animal or an idiot. It appears then that psychology is not likely to turn over a defined portion of its field to 'social psychology' leaving the residue to constitute the domain of ' individual psychology.'

How is it with sociology?

In consequence of imitation, interference, conflict, discussion, compromise, etc., we find people ranged into great alignments which I have termed 'social planes' and 'social currents' - the former referring to the mental uniformities produced by tradition, convention and rational imitation, the latter referring to the transient uniformity seen in mobs, 'booms,' panics, stampedes, 'landslides,' crazes and fads. These unities are purely mental and do not imply anything in the way of combined action or practical coöperation. The study of them can very naturally be termed 'social psychology.' Beyond this comes the study of the groupings of men for the realization of joint purposes by means of combined effort. This branch of sociology might well be termed 'social morphology,' the study of social forms. It is not for a moment to be supposed that the consideration of human groupings such as family, clan, tribe, nation, society, union, church, corporation, or party does not involve attention to many psychological processes as, for example, the emergence of a group consciousness, the formation of a group will, the reaction of the group self upon the personal self. Nevertheless, the principal determinant factors in the life history of the group are to be sought in its constitution and form as, for example, the number of persons associated, whether they are alike or dissimilar, equal or graded, assembled or dispersed, in direct relations or in indirect relations, in constant touch or in occasional touch, whether their association is open or exclusive, public or secret, for general ends or for specific ends, whether the coöperation of the group is guided by the will of a preponderant number or by designated power holders, and whether these power holders are removable or ir- 
removable, absolute or responsible, chosen for term or for life, limited in their powers or unlimited.

According to this view the theory of society (neglecting for the present such helpful basement sciences as demography, and ' mesology,' the study of the reaction of the physical environment) would consist of social psychology and social morphology. If the distinction drawn between these branches is reasonable and helpful, it would seem that sociology has better grounds for appropriating the term ' social psychology' than las psychology.

The writer is aware that the above view is not consistent at all points with his past expressions. Moreover, it may not agree with conclusions he will hereafter reach. There is no reason, however, why the issue presented may not be discussed strictly on its merits without ad hominem argument. The writer recognizes that the matter in dispute is one of scientific convenience merely, and he presents his views in the hope that they will call forth whatever weighty reasons exist on the other side of the question.

Edward Alsworth Ross, Professor of Sociology, University of Wisconsin. 